\title{
The Physiological effects of Piriformospora indica on some crop plants
}

\author{
b- Alleviation effects on stress by Salinity.
}

\author{
Ahmed M.A. Mazen, Osman M.O. El Maghraby and Shereen Abd Elmohsen Ebaid Nasr* \\ Botany Department, Faculty of Science, Sohag University, Sohag 82534, Egypt.
}

Rec. 6 Oct, 2014 Accept. 9 Nov, 2014

\begin{abstract}
The root endophytic fungus Piriformospora indica has been shown to increase resistance against abiotic salinity stress in some crop plants: Vicia faba, Lupinus termis, Arachis hypogaea and Hibiscus sabdariffa. The presence of the fungus reduced the effect of the salinity on the growth rate; and enhanced the photosynthetic processes and protein contents. Moreover, water relations were improved under the effect of the fungus. It was found that, the treated plants by Piriformospora indica reduced the negative effects of salinity on the growth of these plants. From the obtained results, it can be concluded that, Vicia faba, Lupinus termis, Arachis hypogaea and Hibiscus sabdariffa can be cultivated in moderated salinity lands in the presence of root endophyte fungus Piriformospora indica.
\end{abstract}

Key words: Piriformospora indica, salinity stress, Vicia faba, Lupinus termis, Arachis hypogaea and Hibiscus sabdariffa.

\section{Introduction}

High salt concentrations in soil and irrigation water are a major threat to agricultural production in arid and semiarid regions. The presence of excess ions in the rhizosphere causes injury to plant roots, followed by their gradual accumulation in the aerial parts with heavy damage to plant metabolism, which leads to stunted growth and reduced yield (Shannon, 1997). Salt stress has been found to disrupt several morphological, physiological and biochemical processes, many of which are seen at plant cellular levels (Maslenkova $e t$ $a l .$, 1999). Many of important salinity effects in plants are including: Hyperionic and hyperosmotic effects, inhibition of enzyme activities in metabolic pathways, decreased carbon-use efficiency, decreased germination percentage, reduction in photosynthesis and the decomposition of protein and membrane structures (Ali Asghar Bagheri et al., 2013). Plants have evolved complex mechanisms to counter $\mathrm{NaCl}$ toxicity and low water potential in soil caused by salinity as well as drought (reviewed by Munns \& Tester, 2008). Furthermore, mutualistic symbiosis with mycorrhizal and endophytic fungi can confer salt tolerance to plants and decrease yield losses in cultivated crops grown in saline soils (Rodriguez et al., 2004). Recently, a root-endophytic basidiomycete, Piriformospora indica, was used to improve plant resistance against root and leaf diseases and alleviate salt stress in barley (Waller et al., 2005).

Piriformospora indica was isolated from the rhizosphere of Prosopis juliflora and Zizyphus nummularia in the Thar Desert in Rajasthan, India (Verma et al., 1998). This fungus colonizes root sand increases the biomass of both monocot and eudicot plants (Varma et al., 1999). In contrast to arbuscular mycorrhizal fungi, $P$. indica can be easily grown on synthetic media allowing for large-scale propagation and a possible use in plant production.

Earlier studies were demonstrated that salt-treated barley showed reduction in metabolic activity and respiration rates (Criddle et al., 1989; Jolivet et al., 1990).

Drought, salt and temperature extremes all induce the accumulation of reactive oxygen species (ROS), such as superoxide, hydrogen peroxide and hydroxyl radicals (Apel \& Hirt, 2004). Plants are endowed with an array of radical scavengers and antioxidant enzymes that act in concert to alleviate oxidative stress. An imbalance between antioxidant defences and the amount of ROS results in

\footnotetext{
* Corresponding author:

Dr. Shereen Abd Elmohsen Ebaid Nasr
}

$凶$ shereen.nasr1@yahoo.com 
cellular injury (Foyer \& Noctor, 2000). An increasing body of evidence suggested that high salinity induced oxidative stress in plants that was at least partly responsible for tissue damage (Hernández et al., 2000; Mittova et al., 2004). Several studies had demonstrated that salinity increases antioxidant activities in salt-tolerant plants above the levels found in salt-sensitive plants (Gossett et al., 1994; Gueta-Dahan et al., 1997; Mittova et al., 2004).

The aim of this study was to investigate the fungus' potential to protect Vicia faba, Lupinus termis, Arachis hypogaea and Hibiscus sabdariffa from salt stress. So plant growth parameters, photosynthetic processes, water relation, protein content and profile, proline content, antioxidant enzyme activity and some element content in plant tissues were determined.

\section{Material and Methods \\ Plant material:}

Seeds of four plants were obtained from the agriculture research center, Shandaweel Agriculture Research Station, Sohag, Egypt. Plants seeds were surface sterilized for $1 \mathrm{~min}$ in $75 \%$ ethanol and then washed three times by sterilized distilled water for $5 \mathrm{~min}$ each.

Soil:

The soil used in the experiments was mixture of sand/clay (2:1) which was sterilized at $180^{\circ} \mathrm{C}$ for $30 \mathrm{~min}$ in oven before seed sowing.

\section{Cultivation of fungus:}

The fungus was maintained on Kafer's medium (Kafer, 1977). The fungus grows in liquid medium. The culture medium was inoculated with agar containing fungal discs and incubated at $28 \pm 2^{\circ} \mathrm{C}$ under constant shaking conditions (100 rpm) in dark for 14 days.

\section{Experimental design:}

The plastic pots containing $2 \mathrm{~kg}$ soil were divided into ten groups and treated as the follow (3 pots were used for each treatment):

a- Plants of the $1^{\text {st }}$ group were left without any treatments (control).

b- Plants of the $2^{\text {nd }}$ group were treated with $100 \mathrm{mM} \mathrm{NaCl}$.

c- Plants of the $3^{\text {rd }}$ group were treated with $100 \mathrm{mM} \mathrm{NaCl}$ and inoculated with $P$. indica.

Experiment was carried out in the open field greenhouse of Botany department, Faculty of science, Sohag University. Plants were carefully watered every three days with tap water. The previous design was carried out for all plant species.

After 14 days old for plant growth, irrigated plant groups numbered 3 with $200 \mathrm{ml}$ of $P$. indica liquid culture. After other two weeks, irrigated plants groups numbered 2 and 3 by $100 \mathrm{mM} \mathrm{NaCl}$. Then collected the plants after 14 days and did the following experiment:

\section{Growth parameters:}

Four weeks after inoculation, whole plants (all species) were harvested and divided into roots and shoots, and fresh \& dry weights and length of each were determined.

\section{Determination of photosynthetic process: a- Photosynthetic pigments:}

The photosynthetic pigments viz, chlorophyll a, chlorophyll $\mathrm{b}$ and carotenoids, were determined using the spectrophotometric method recommended by Metzner et al., (1965). It was possible to determine the concentrations of the pigment fractions (chlorophyll a, chlorophyll b and carotenoids) as $\mathrm{mg} / \mathrm{ml}$ using the following equations:

Chlorophyll $\mathrm{a}=10.3 \mathrm{E}_{663}-0.918 \mathrm{E}_{644}=$ $\mu \mathrm{g} / \mathrm{ml}$

Chlorophyll $\mathrm{b}=19.7 \mathrm{E}_{644}-3.87 \mathrm{E}_{663}=$ $\mu \mathrm{g} / \mathrm{ml}$

Carotenoids $=4.2$ E452.5- $(0.0264$ chlorophyll $\mathrm{a}+0.0462$ chlorophyll $\mathrm{b}$ ) = $\mu \mathrm{g} / \mathrm{ml}$

Finally, the pigment fractions were calculated as $\mathrm{mg} / \mathrm{gm}$ fresh weight.

b- Photosynthetic rate and intercellular $\mathrm{CO}_{2}$ :

Leaves of control and treated plants were subjected to analyses of net photosynthetic rate (A) and sub-stomatal $\mathrm{CO}_{2}(\mathrm{Ci})$ using LCi Portable Photosynthesis System.

Plant-water relationship parameters a- Transpiration rate and stomatal conductance:

Leaves of control and treated plants were subjected to analyses of net transpiration rate (E) and stomatal conductance (Gs) using LCi Portable Photosynthesis System.

b- Relative water content (RWC):

The RWC stated by Slatyer in 1967, express the in percentage the water content at a given time and tissue as related to the water content at full turgor:

$\mathrm{RWC}=(\mathrm{FW}-\mathrm{DW}) /(\mathrm{TW}-\mathrm{DW})$ 


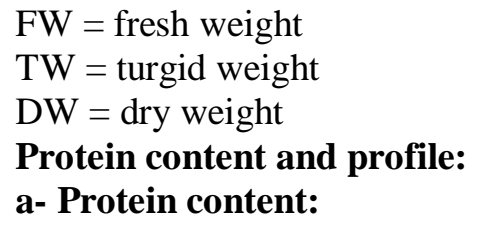

Total soluble, insoluble and total proteins were determined using the method of Lowry et al. (1951). Dry plant material (0.5 g) was homogenized in $5 \mathrm{ml}$ phosphate buffer $(\mathrm{pH}=$ 7.0) and centrifuged. The extractants were treated with appropriate reagents and the optical densities were read at $570 \mathrm{~nm}$.

\section{b- Protein profile:}

Electrophoresis detection of protein in plant tissue by sodium dodycle sulphate polyacrylamide gel electrophoresis (SDSPAGE) following the method described by Laemmli (1970) was used in the present study.

\section{Free proline}

Proline was determined following Bates et al. (1973). Dry plant material (0.5 g) was homogenized in $10 \mathrm{ml}$ of $3 \%$ sulfosalicylic acid and the homogenate filtered. The filtrate $(2 \mathrm{ml})$ was treated with $2 \mathrm{ml}$ acid ninhydrin and $2 \mathrm{ml}$ of glacial acetic acid, then with 4 $\mathrm{ml}$ of toluene. Absorbance of the colored solutions was read at $520 \mathrm{~nm}$.

\section{Antioxidant enzyme activity: a- CAT assay.}

CAT activity was assayed by measuring the initial rate of $\mathrm{H}_{2} \mathrm{O}_{2}$ disappearance using the method of Beers \& Sizer (1952). $1 \mathrm{ml}$ of catalase assay reaction mixture contained $0.05 \mathrm{mM}$ sodium phosphate buffer ( $\mathrm{pH}$ 7.0), $20 \mathrm{ml}$ enzyme extract and $1 \mathrm{mM} \mathrm{H}_{2} \mathrm{O}_{2}$. The decrease in $\mathrm{H}_{2} \mathrm{O}_{2}$ was followed by a decline in A240, and the activity [U (mg protein) $\left.{ }^{-1}\right]$ was calculated using a molar absorption coefficient of $40 \mathrm{mM}^{-1} \mathrm{~cm}^{-1}$ for $\mathrm{H}_{2} \mathrm{O}_{2}$.

\section{b- Peroxidase assay.}

The peroxidase activity was determined as described by Machly and Chance (1954). A $0.5 \mathrm{gm}$ of fresh leaf sample was weighed and ground well in a mortar with little quantity of chilled phosphate buffer at $\mathrm{pH}$ 6.6 and filtered through a double layered muslin cloth to remove the pulp, made up to $25 \mathrm{ml}$ and centrifuged for 30 minutes at 2000 rpm at $4{ }^{\circ} \mathrm{C}$. The clear extract was used as enzyme source. $3 \mathrm{ml}$ of $0.05 \mathrm{M}$ guaiacol solution was pipetted out into a test tube to which $0.1 \mathrm{ml}$ of enzyme extract was added. Then $0.5 \mathrm{ml}$ of 1 per cent hydrogen peroxide was added, mixed the contents rapidly and the absorbance was measured in calorimeter at $470 \mathrm{~nm}$ at an interval of 20 seconds.

Enzyme activity was calculated by taking the average difference of O.D between two consecutive time intervals and enzyme activity was expressed in terms of OD $\mathrm{sec}^{-}$ ${ }^{1} \mathrm{mg}^{-1}$ protein (i.e. specific activity).

\section{Mineral elements in plant tissues}

The dried and ground samples of leaves $(0.3 \mathrm{~g}$ each) were digested with sulphuric acid and hydrogen peroxide according to the method of Wolf (1982). Na, K, and Ca were determined with a flame photometer (Jenway PFP-7).

\section{Statistical analysis}

Data for all attributes were subjected to a ANOVA one-way analysis of variance and the mean values were compared with the least significance difference (LSD) at 0.05 and 0.01 levels, with the Origin program.

\section{Results \\ Growth:}

To study the ability of colonized plants by $P$. indica to tolerate salinity stress, we were designed experiment for this aim. Plants divided to three groups: $1^{\text {st }}$ were controls, $2^{\text {nd }}$ plants were treated with $100 \mathrm{mM}$ and $3^{\text {rd }}$ plants were treated with P.indica after 2 weeks treated by $100 \mathrm{mM}$. At the end of experimental period growth parameters were measured for both roots and shoots. In generalist, salinity treated plants show significant decreases in fresh, dry weight and length for both roots and shoots compared to control plants. In contrast, treated plants by $P$. indica and salinity appear significant increase in fresh, dry weight and length for both roots and shoots compared to control plants and plants which treated by saline solution.

Moreover, Root fresh weight decreasing ratios in group two (treated by $100 \mathrm{mM}$ $\mathrm{NaCl})$ compared to those in group one (control) were: 14\%, 9\%, 19\% and 32\%, and root dry weight were $16 \%, 24 \%, 18 \%$ and $6 \%$, and shoot fresh weight were $19 \%, 26 \%$, $2 \%$ and $26 \%$, and shoot dry weight were $18 \%, 35 \%, 7 \%$ and $2 \%$, in V. faba, L. termis, A. hypogaea and $H$. sabdariffa, respectively. For root and shoot lengths there is no general trend on effect of salinity on these parameters, but depend on plant identity. In opposite side, plants belong to group three $(P$. indica $+100 \mathrm{mM} \mathrm{NaCl})$ show enhancement in growth parameters 
compared to plants in group two $(100 \mathrm{mM}$ $\mathrm{NaCl}$ ), where root fresh weight increasing ratios were $62 \%, 149 \%, 80 \%$ and $87 \%$, and root dry weight were $19 \%, 107 \%, 47 \%$ and $73 \%$, and shoot fresh weight were $86 \%$, $39 \%, 103 \%$ and $92 \%$, and shoot dry weight were $44 \%, 61 \%, 109 \%$ and $30 \%$, root length were $40 \%, 22 \%, 7 \%$ and $12 \%$, and shoot length were $25 \%, 10 \%, 37 \%$ and $2 \%$, in $V$. faba, L. termis, A. hypogaea and $H$. sabdariffa, respectively (Fig. 1).

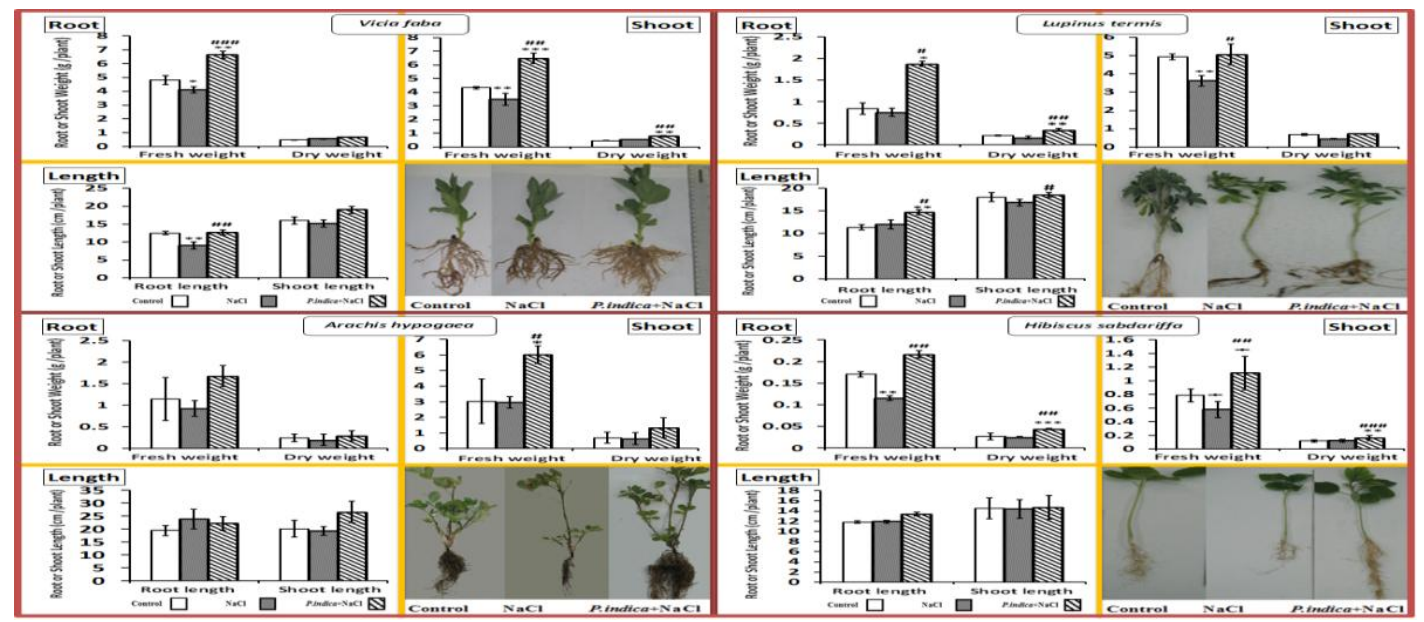

Figure 1: Effect of salinity stress $(100 \mathrm{mM} \mathrm{NaCl})$, and inoculation with $P$. indica under salinity stress $(100 \mathrm{mM}$ $\mathrm{NaCl}$ ) on root and shoot fresh, dry weight and length of experimental plants. Error bar in each column equals the standard deviation from the mean. Difference is significant at $\mathrm{P}<0.05(*)$, at $\mathrm{P}<0.01(* *)$, and at $\mathrm{P}<0.001(* * *)$ (compared with control plants). Difference is significant at $\mathrm{P}<0.05\left({ }^{\#}\right)$, at $\mathrm{P}<0.01\left({ }^{\#}\right)$, and at $\mathrm{P}<0.001\left({ }^{\# \#}\right)$ (Compared with treated plants with $100 \mathrm{mM} \mathrm{NaCl}$ ), according the One-Way ANOVA.

\section{Photosynthesis:}

Recorded results for photosynthetic pigments content in fresh leaves plants tissue represented by chlorophyll a, chlorophyll $\mathrm{b}$ and carotenoids appeared significant decrease in group two plants (treated by $100 \mathrm{mM} \mathrm{NaCl}$ ) compared to control plants. Moreover, plants in group three (colonized by $P$. indica + treated by $100 \mathrm{mM} \mathrm{NaCl}$ ) recorded enhancement in photosynthetic pigments content compared to group two plants (treated by $100 \mathrm{mM} \mathrm{NaCl}$ ) in all plant species. Moreover, decreasing ratio in total pigments content in group two plants (treated by $100 \mathrm{mM} \mathrm{NaCl}$ ) compared to control plants were; $5 \%, 14 \%, 3 \%$ and $26 \%$, in V. faba, L. termis, A. hypogaea and $H$. sabdariffa, respectively. Furthermore, enhancement in total pigments contents in group three plants (colonized by $P$. indica + treated by $100 \mathrm{mM} \mathrm{NaCl}$ ) compared to group two plants (treated by $100 \mathrm{mM} \mathrm{NaCl}$ ) were; $7 \%, 54 \%, 11 \%$ and $32 \%$, in V. faba, L. termis, A. hypogaea and $H$. sabdariffa, respectively (Fig. 2).

Photosynthetic rate:

Under effect of salinity, photosynthetic rate appear negative effect in group two plants (treated by $100 \mathrm{mM} \mathrm{NaCl}$ ) compared to control plants were; $35 \%, 35 \%, 34 \%$ and $18 \%$, in V. faba, L. termis, A. hypogaea and $H$. sabdariffa, respectively. Moreover, colonized plants can overcome on bad effect of salinity by enhancing the photosynthetic rate. where, significant increasing in group three plants (colonized by $P$. indica + treated by $100 \mathrm{mM} \mathrm{NaCl}$ ) compared to group two plants (treated by $100 \mathrm{mM} \mathrm{NaCl}$ ) reach up to $35 \%, 137 \%, 57 \%$ and $93 \%$, in V. faba, L. termis, A. hypogaea and $H$. sabdariffa, respectively (Fig. 2).

Intercellular $\mathrm{CO}_{2}$ :

Furthermore, the intercellular $\mathrm{CO}_{2}$ concentration (Ci) showed non-significant change in cases group two compared to group one plants and group three compared to group two plants (Fig. 2). 


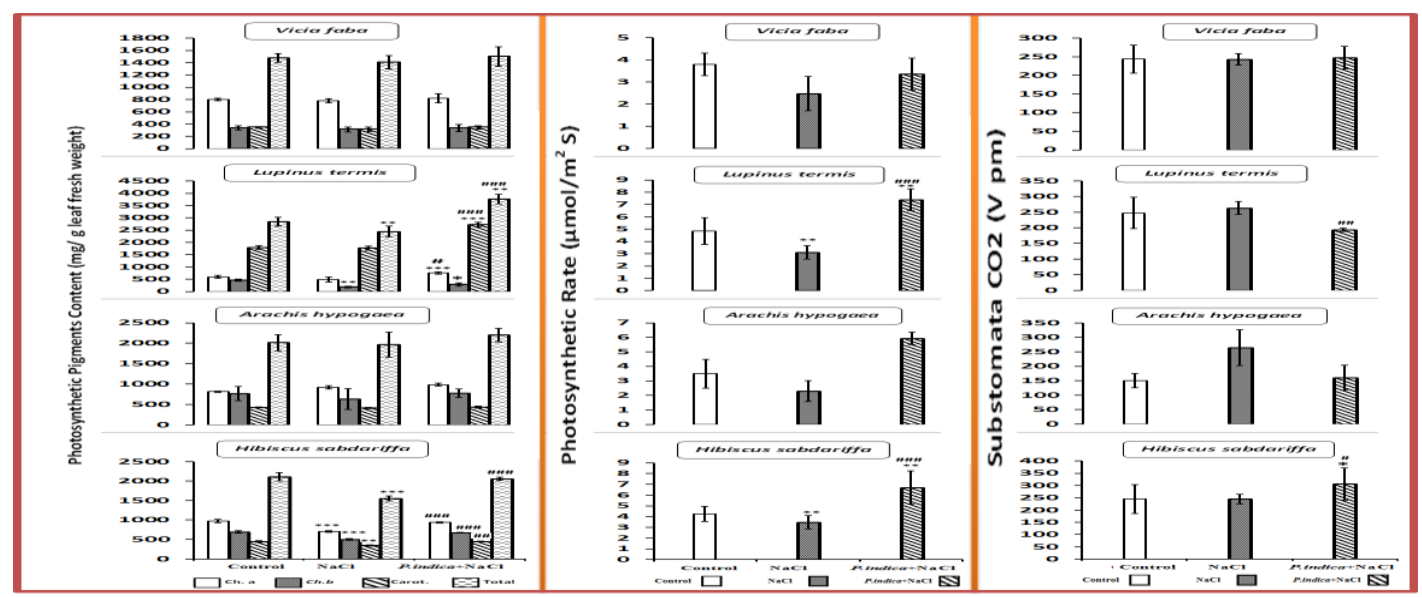

Figure 2: Effect of salinity stress $(100 \mathrm{mM} \mathrm{NaCl})$, and inoculation with $P$. indica under salinity stress $(100 \mathrm{mM}$ $\mathrm{NaCl}$ ) on leaf content of photosynthetic pigments, photosynthetic rate and intercellular $\mathrm{CO}_{2}$ of experimental plants. Error bar in each column equals the standard deviation from the mean. Difference is significant at $\mathrm{P}<0.05(*)$, at $\mathrm{P}<0.01(* *)$, and at $\mathrm{P}<0.001(* * *)$ (compared with control plants). Difference is significant at $\mathrm{P}<0.05(\#)$, at $\mathrm{P}<0.01$ $\left({ }^{\# \#}\right)$, and at $\mathrm{P}<0.001\left(^{\# \# \#)}\right.$ (Compared with treated plants with $100 \mathrm{mM} \mathrm{NaCl}$ ), according the One-Way ANOVA.

\section{Transpiration rate $\&$ stomatal L. termis, A. hypogaea and $H$. sabdariffa, conductance: respectively (Fig. 3).}

Gas exchange parameters, i.e. Transpiration rate (E) and stomatal conductance (Gs) had been estimated in experimented plants in response to salinity (group two) and colonized plants by $P$. indica and salinity (group three). Moreover, these parameters appeared significant decrease in group two plants (treated by 100 $\mathrm{mM} \mathrm{NaCl}$ ) compared to group one plants (control). In contrast, these parameters showed a significant increases in group three plants (colonized by $P$. indica + treated by $100 \mathrm{mM} \mathrm{NaCl}$ ) compared to group two plants (treated by $100 \mathrm{mM} \mathrm{NaCl}$ ), in $V . f a b a$,

\section{Relative Water Content:}

Salt treated inhibited relative water content in group two plants, while colonized plants by $P$. indica alleviate salt effects. Moreover, inhibited ratio were $7 \%, 6 \%, 3 \%$ and $3 \%$ in group two plants (treated by 100 $\mathrm{mM} \mathrm{NaCl}$ ) compared to group one plants (control). On other hand, alleviatory ratio were; $11 \%, 8 \%, 5 \%$ and $11 \%$, in group three plants (colonized by $P$. indica + treated by $100 \mathrm{mM} \mathrm{NaCl}$ ) compared to group two plants (treated by $100 \mathrm{mM} \mathrm{NaCl}$ ), in $V . f a b a$, L. termis, A. hypogaea and H. sabdariffa, respectively (Fig. 3).

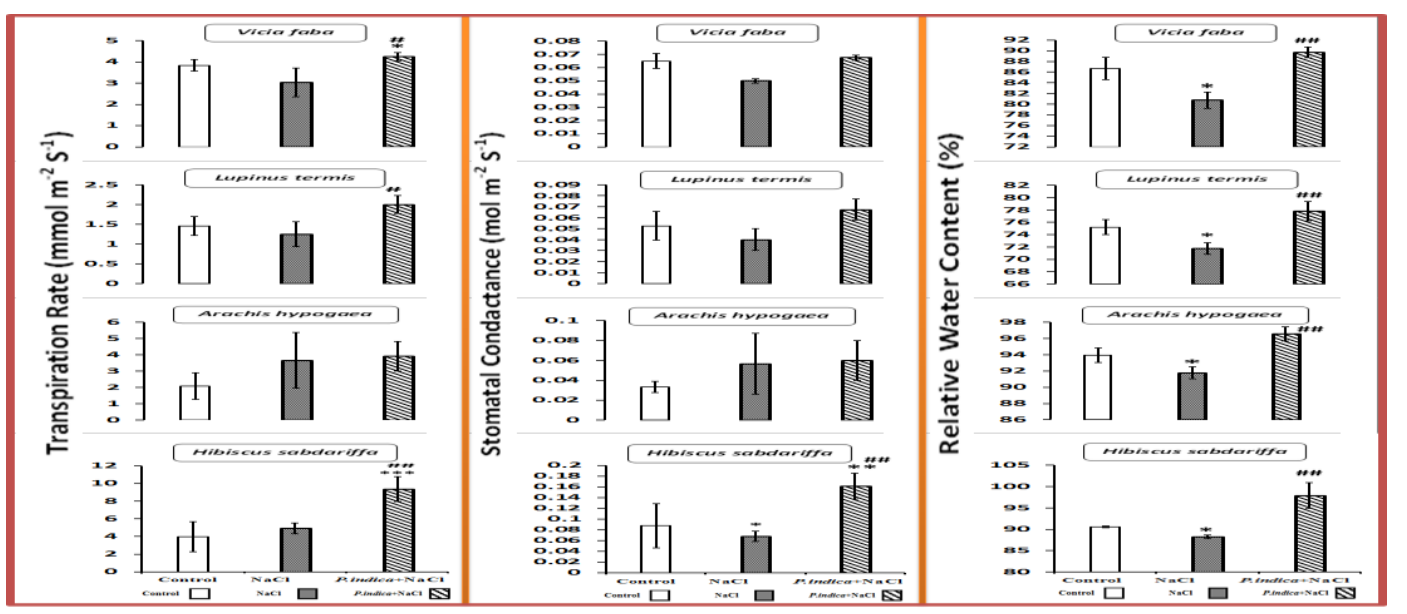

Figure 3: Effect of salinity stress $(100 \mathrm{mM} \mathrm{NaCl})$, and inoculation with $P$. indica under salinity stress $(100 \mathrm{mM}$ $\mathrm{NaCl}$ ) on transpiration rate, stomatal conductance and relative water content of experimental plants. Error bar in each column equals the standard deviation from the mean. Difference is significant at $\mathrm{P}<0.05(*)$, at $\mathrm{P}<0.01(* *)$, and at $\mathrm{P}<0.001(* * *)$ (compared with control plants). Difference is significant at $\mathrm{P}<0.05\left({ }^{*}\right)$, at $\mathrm{P}<0.01\left(^{(\#)}\right)$, and at $\mathrm{P}<0.001{ }^{\left({ }^{\# \#}\right)}$ (Compared with treated plants with $\left.100 \mathrm{mM} \mathrm{NaCl}\right)$, according the One-Way ANOVA. 


\section{Protein content and profile:}

Fig (4) show that change in protein fragments (soluble, insoluble and total protein) content in both group two and group three plants were non-significant in four experimental plants. But protein profile appears induced polypeptide proteins, mainly in group two plants. The results supported that an addition of P.indica alleviated the effects of $\mathrm{NaCl}$ on protein profile.

\section{Proline content:}

Proline accumulation increase in group two plants (treated by $100 \mathrm{mM} \mathrm{NaCl}$ ) compared to group one plants (control). Moreover, proline accumulation decrease in group three plants (colonized by $P$. indica + treated by $100 \mathrm{mM} \mathrm{NaCl}$ ) compared to group two plants (treated by $100 \mathrm{mM} \mathrm{NaCl}$ ) in all plant species except in $H$. sabdariffa, where proline accumulation increase in case plants colonized by $P$. indica + treated by $100 \mathrm{mM}$ $\mathrm{NaCl}$ compared to those treated by $100 \mathrm{mM}$ $\mathrm{NaCl}$ (Fig. 5).

\section{Antioxidant enzymes:}

CAT and peroxidase activity were higher in group two plants shoots as compared with group one plants, and in group three plants compared with group two plants (Fig. 6).

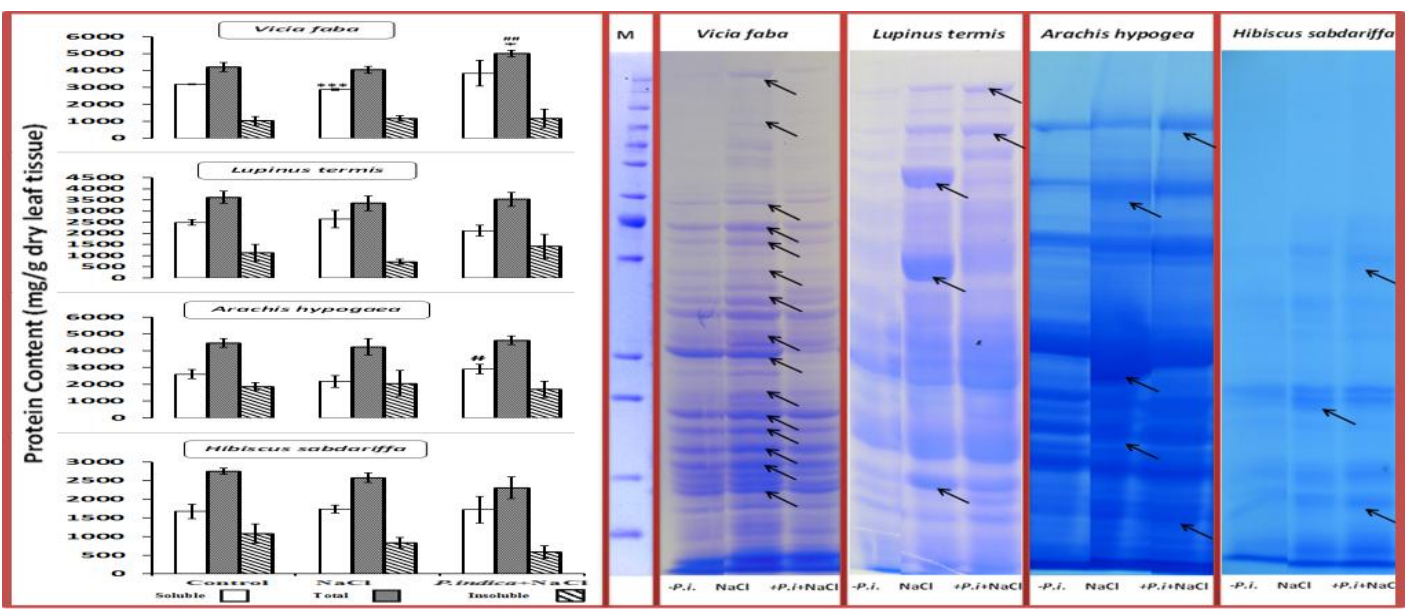

Figure 4: Effect of salinity stress $(100 \mathrm{mM} \mathrm{NaCl})$, and inoculation with $P$. indica under salinity stress $(100 \mathrm{mM}$ $\mathrm{NaCl}$ ) on leaf content of protein and protein profile of experimental plants. Error bar in each column equals the standard deviation from the mean. Difference is significant at $\mathrm{P}<0.05(*)$, at $\mathrm{P}<0.01(* *)$, and at $\mathrm{P}<0.001(* * *)$ (compared with control plants). Difference is significant at $\mathrm{P}<0.05\left({ }^{\#}\right)$, at $\mathrm{P}<0.01(\#)$, and at $\mathrm{P}<0.001\left({ }^{\# \#}\right)$ (Compared with treated plants with $100 \mathrm{mM} \mathrm{NaCl}$ ), according the One-Way ANOVA.

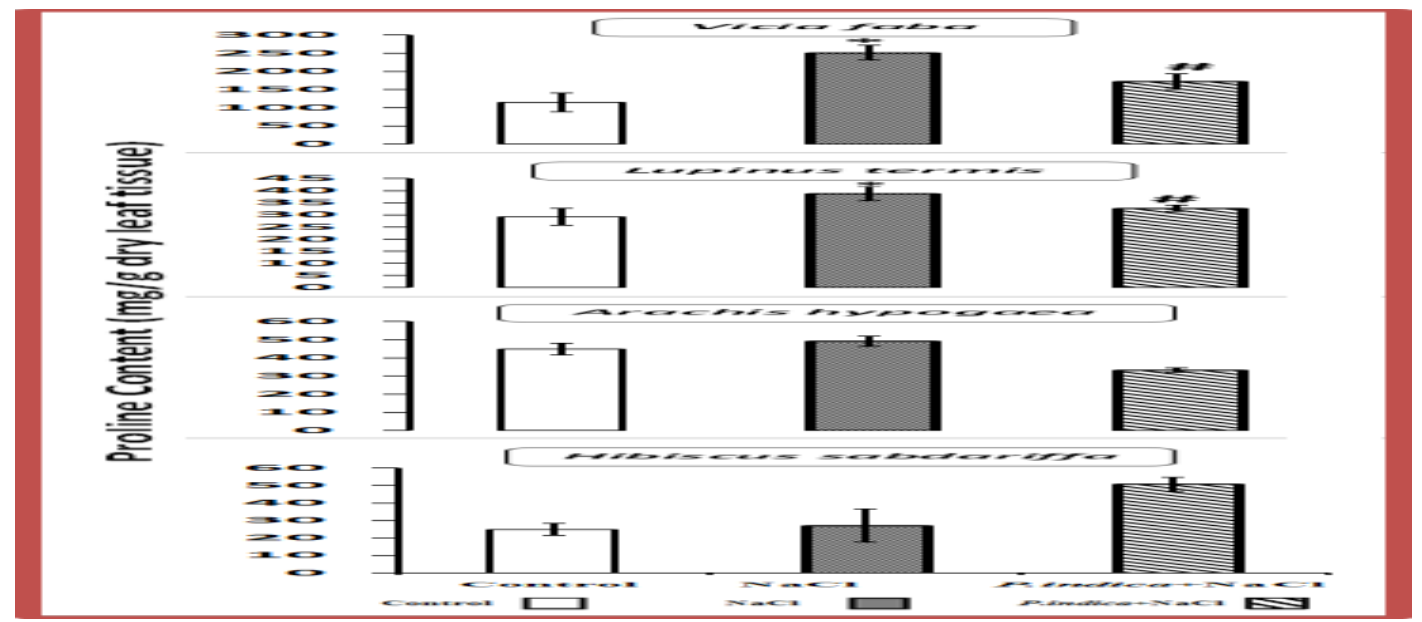

Figure 5: Effect of salinity stress $(100 \mathrm{mM} \mathrm{NaCl})$, and inoculation with $P$. indica under salinity stress $(100 \mathrm{mM}$ $\mathrm{NaCl}$ ) on leaf content of proline of experimental plants. Error bar in each column equals the standard deviation from the mean. Difference is significant at $\mathrm{P}<0.05(*)$, at $\mathrm{P}<0.01(* *)$, and at $\mathrm{P}<0.001$ (***) (compared with control

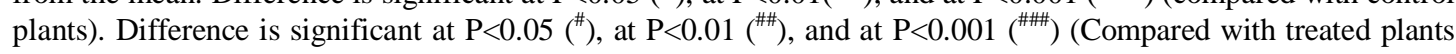
with $100 \mathrm{mM} \mathrm{NaCl}$ ), according the One-Way ANOVA. 


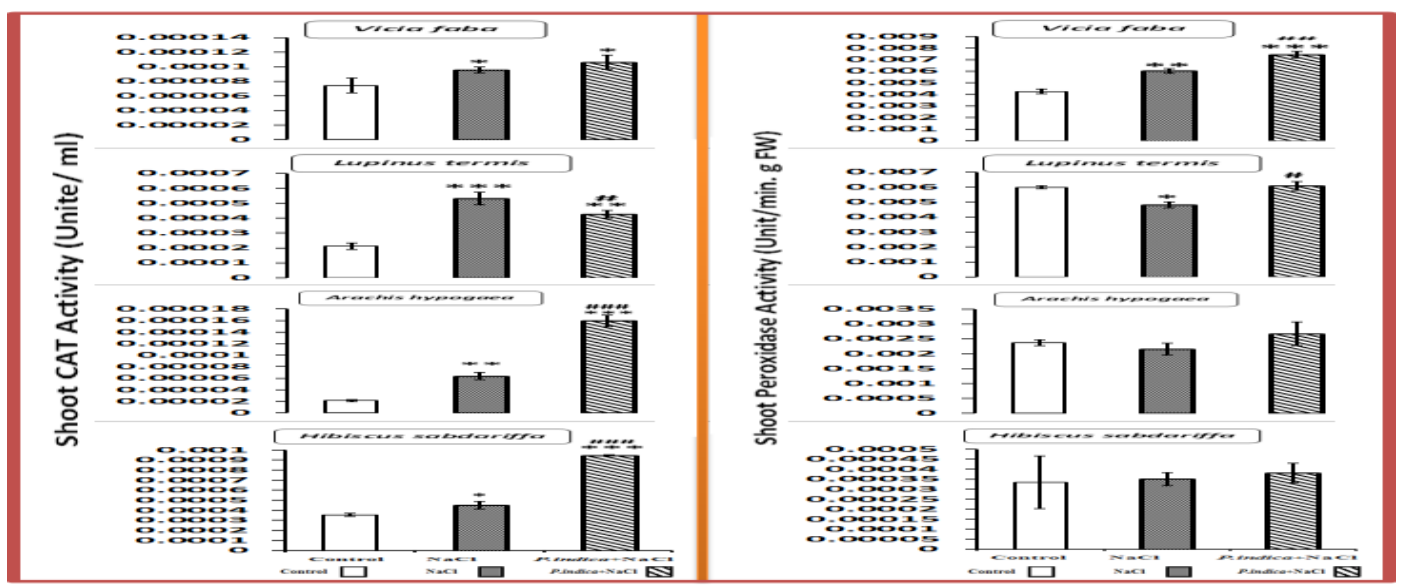

Figure 6: Effect of salinity stress $(100 \mathrm{mM} \mathrm{NaCl})$, and inoculation with $P$. indica under salinity stress $(100 \mathrm{mM}$ $\mathrm{NaCl})$ on enzyme activity of experimental plants. Error bar in each column equals the standard deviation from the mean. Difference is significant at $\mathrm{P}<0.05(*)$, at $\mathrm{P}<0.01(* *)$, and at $\mathrm{P}<0.001$ (***) (compared with control plants). Difference is significant at $\mathrm{P}<0.05(\#)$, at $\mathrm{P}<0.01\left({ }^{\# \#}\right)$, and at $\mathrm{P}<0.001\left(^{(\# \#)}\right.$ ) (Compared with treated plants with 100 $\mathrm{mM} \mathrm{NaCl}$ ), according the One-Way ANOVA.

\section{Element content:}

Effect of salinity on element $(\mathrm{Na}, \mathrm{Ca}, \mathrm{K})$ content exhibited variable content from plant to other, and from element to other. Moreover, sodium content was increased in group two plants compared to group one plants. Increasing ratios were, $25 \%, 12 \%$, $200 \%$ and $20 \%$ in V. faba, L. termis, A. hypogaea and $H$. sabdariffa, respectively. On other hand, sodium content decrease in group three plants compared to group two plants, in all experimental plant species. Decreasing ratios were, $-13 \%,-7 \%,-68 \%$ and $-6 \%$ in $V$. faba, L. termis, A. hypogaea and $H$. sabdariffa, respectively (Fig. 7).

Calcium under salinity stress exhibited decrease in their content in $V$. faba and $A$. hypogea, $-57 \%$ and $-12 \%$, respectively. But we obtained on opposite results in other plant species, where calcium content was increase in group two compared to group one plants, in case $L$. termis and $H$. sabdariffa, $25 \%$ and $43 \%$, respectively. In general, calcium content in group three increases than in those in group two plants. Increasing ratios were, $73 \%, 18 \%, 12 \%$ and $40 \%$, in V. faba, L. termis, A. hypogaea and $H$. sabdariffa, respectively (Fig. 7).

Potassium under salinity stress didn't exhibit strong change in its content in group two compared to group one plants. Decreasing ratios were, $-11 \%,-6 \%,-5 \%$ and $-3 \%$, in $V$. faba, L. termis, A. hypogaea and $H$. sabdariffa, respectively. Group three showed increasing in potassium content compared to group two plants. Increasing ratios were, 9\%, $54 \%, 76 \%$ and $32 \%$, in V. faba, L. termis, A. hypogaea and $H$. sabdariffa, respectively (Fig.

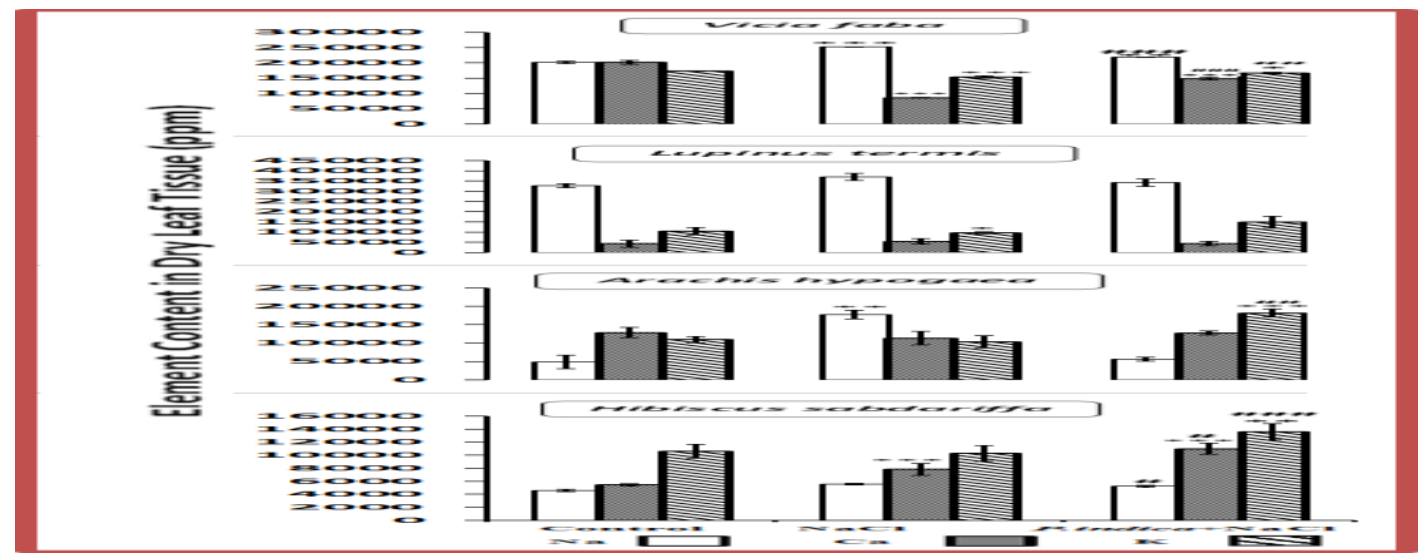

Figure 7: Effect of salinity stress $(100 \mathrm{mM} \mathrm{NaCl})$, and inoculation with $P$. indica under salinity stress $(100 \mathrm{mM}$ $\mathrm{NaCl})$ on metal content $(\mathrm{Na}, \mathrm{Ca}$ and $\mathrm{K})$ of experimental plants. Error bar in each column equals the standard deviation from the mean. Difference is significant at $\mathrm{P}<0.05(*)$, at $\mathrm{P}<0.01(* *)$, and at $\mathrm{P}<0.001$ (***) (compared 
with control plants). Difference is significant at $\mathrm{P}<0.05\left({ }^{\#}\right)$, at $\mathrm{P}<0.01\left({ }^{\#}\right)$, and at $\mathrm{P}<0.001\left({ }^{(\# \#)}\right.$ (Compared with treated plants with $100 \mathrm{mM} \mathrm{NaCl}$ ), according the One-Way ANOVA.

\section{Discussion}

\section{Growth:}

It has been shown that this fungus ( $P$. indica) can grow even under conditions of high salt concentration of $219.14 \mathrm{mM}$, while its growth was inhibited at salt concentration 438.27 mM (Chordia P., 2011, Kumar M., et al., 2012).

We analyzed the fungus' potential to protect V. faba, L. termis, A. hypogaea and $H$. sabdariffa from salt stress.

In the present study, the effect of salinity stress on plant biomass appeared significant decrease in experimental plant species. Moreover, this decrease in plant biomasses could alleviate by presence of $P$. indica colonized in plant roots under the same condition of salinity stress. These results agree with other observation on barley plants. Frank Waller et al., 2005, demonstrated that the detrimental effect of moderate salt stress on barley plants was completely abolished by $P$. indica, as shown by the fact that infested plants produced higher biomass than did non stressed control plants under these conditions. However, under high salt-stress conditions, both non infested and infested plants exhibited a severe biomass reduction.

Helmut Baltruschat et al., 2008, mentioned that the biomass of the youngest developed leaves of barley plants slightly decreased under saline conditions, while older leaves exhibited chlorosis and subsequent necrosis. Mild salt stress (100 $\mathrm{mM} \mathrm{NaCl}$ ) caused a slight, but not significant, reduction in shoot fresh weight of barley plants. However, high-salt (300 $\mathrm{mM} \mathrm{NaCl}$ ) treatment caused substantial biomass reduction in uncolonized and $P$. indica colonized cv. Ingrid and cv. California Mariout. Compared with uncolonized plants, shoot fresh weight of $P$. indica-colonized barley cv. Ingrid was enhanced about twofold under both control and saline conditions. Even after exposure to $300 \mathrm{mM}$ $\mathrm{NaCl}, P$. indica colonized plants produced shoot biomass comparable to uncolonized Ingrid barley grown under nonsaline conditions.

\section{Photosynthesis process:}

In this research, photosynthetic pigments content in salinity treated plants were appeared significant decreases, on other hand, $P$. indica colonized plants under the same salinity condition was showed significant increase in photosynthetic pigments.

The reduction in photosynthesis in the salinity-treated plants was reported by many researchers (Downton 1977; Ball and Farquhar 1984; Behboudian et al. 1986). The adverse effects of high $\mathrm{NaCl}$ on chlorophyll concentration have previously been shown in rice (Yeo et al. 1990), barley (Belkhodja et al. 1994), tomato (Kaya et al. 2001), and pepper (Kaya et al. 2009). In droughtinduced Chinese cabbage, the presence of $P$. indica retards the decrease in the protein levels of representative components of the thylakoid membrane and of enzymes located in the plastid stroma (Sun et al. 2010). Sun et al. (2010) showed that $P$. indica retarded the drought-induced Chinese cabbage decline in the photosynthetic efficiency and the degradation of chlorophylls and thylakoid proteins. Under saline condition, $P$. indica colonization increased chlorophyll content in wheat, and the $P$. indica inoculated plants had greener leaves than non- $P$. indica inoculated plants under saline conditions (Zarea et al. 2011b).

Photosynthesis is important for growth and development of green plants and can be severely affected by environmental stress (Jogawat A, et al., 2013). In the present study, we focused on $\mathrm{Chl}$ and carotenoid levels, since they play a vital role in photosynthesis and photoprotection. Chl and carotenoids can be degraded due to high sodium ion toxicity during salt stress. Several crops have been reported of having reduced $\mathrm{Chl}$ a and $\mathrm{Chl} b$ concentrations upon salinity stress, e.g., cabbage (Brassica oleracea var. capitata L.), sunflower (Heliantus annuus L.), wheat (Triticum aestivum L.), and sugarcane (Saccharum officinarum L.)( Jamil M, et al.,2007; Ashraf M and Sultana R, 2000; Akram NA and Ashraf M, 2011; Arfan M, et al., 2007; Perveen S, et al., 2010; Ashraf M. and Harris PJC, 2013; Gomathi R and Rakkiyapan P. , 2011). The extent of reduction of the pigment content depends on the salt tolerance of the plant species. 
In case of some plant species (wheat, pea, sunflower, etc.), the Ch content is a potential biochemical indicator of salt tolerance, although this is not true for all species and cultivars (Ashraf M. and Harris PJC, 2013). In a study with sugarcane, Gomathi and Rakkiyapan (2011) found that salt stress at various plant growth stages caused a marked reduction in $\mathrm{Chl}$ and carotenoid contents, but salt-tolerant varieties exhibited higher membrane stability and pigment contents.

\section{Water relations:}

Transpiration rate:

It is generally known that higher stomatal conductance in plants increases $\mathrm{CO}_{2}$ diffusion into the leaf thereby favoring higher photosynthetic rates. Higher net $\mathrm{CO}_{2}$ assimilation rates could in turn favour a higher biomass and higher crop yields (Taiz \& Zeiger 2002; Flexas et al. 2002).

Pervious searches showed that transpiration rate and stomatal conductance under salt stress were decrease compared to control plants. Muhamed Ashraf et al., (2003) reported that salinity cased decreased in transpiration rate and stomatal conductance in Sesbania aculeate and Phaseolus vulgaris. This supported our results, where appear that in salinity stress transpiration rate and stomatal conductance decrease compared to control plants. Moreover, colonized plants by $P$. indica under salinity condition could overcome on transpiration rate and stomatal conductance decreases.

\section{Relative water content:}

In the present study, leaf relative water content in $V$. faba, L. termis, A. hypogaea and $H$. sabdariffa plants under salinity stress was less than in control plants. Moreover, relative water content in colonized plants under saline condition was higher than plants under salinity stress. Kumar et al. (2009) also reported that relative water content in the leaves of wheat was significantly higher in $P$. indica inoculated than in noninoculated wheat plants under saline conditions.

\section{Proline:}

Under salt stress, plants accumulate some organic solutes such as proline and inorganic ions to maintain higher osmotic adjustment (Yang et al. 2009). Free amino acids are important osmolytes contributing to osmotic adjustment in plants (Hajlaoui et al. 2010). With increasing external salt concentration, free amino acids accumulate in the leaves and roots of maize (Abd-El Baki et al. 2000; Neto et al. 2009; Hajlaoui et al. 2010). Among free amino acids, proline is a contributor to osmotic adjustment in saltstressed maize plants (Hajlaoui et al. 2010). It appears that the presence of the $P$. indica fungus in the roots may modify the osmotic potential of the leaves as they have been shown to influence the composition of the level of proline (Zarea et al. 2011b). Proline accumulation is thought an adaptive feature under salinity stress in $P$. indica (Zarea et al. 2011b). Results also show that the accumulation of proline in wheat is increased by $P$. indica inoculation (Zarea et al. 2011b). The high level of proline enables the plants to maintain osmotic balance when growing under low water potentials (Stewart and Lee 1974). Proline acts as a major reservoir of energy and nitrogen for utilization by plants subjected to salinity stress (Goas et al. 1982; Ashraf and Foolad 2006). In this search, proline accumulations in stressed plants by salinity were higher than control plants. Vicia faba, Lupinus termis and Arachis hypogaea colonized plants by $P$. indica under salinity conditions were proline accumulations less than in non-colonized plants. But Hibiscus sabdariffa colonized plants by $P$. indica under salinity conditions were proline accumulations more than in non-colonized plants.

\section{Enzyme activity:}

Damage to plants that are induced by salt stress may also be a consequence of the production of ROS (reactive oxygen species) (Hernandez et al. 1995). In this regard, plants with high concentrations of antioxidants or antioxidative enzymes are typically more resistant to damage by ROS (Spychalla and Desbough 1990; Dionisio- Sese and Tobita 1998; Jiang and Zhang 2002). Plants are endowed with an array of radical scavengers and antioxidant enzymes that act in concert to alleviate oxidative stress. The induction of ROS-scavenging enzymes, such as superoxide dismutase (SOD), peroxidases (POXs), and catalase (CAT), is the most common mechanism for detoxifying ROS synthesized during stress responses (Wojtaszek 1997; Mittler 2002). An imbalance between antioxidant defenses and the amount of ROS results in cellular injury (Foyer and Noctor 2000). An increasing 
body of evidence suggests that high salinity induces oxidative stress in plants that is at least partly responsible for tissue damage (Herna'ndez et al. 2000; Mittova et al. 2004). Several studies have demonstrated that salinity increases antioxidant activities in salt-tolerant plants above the levels found in salt-sensitive plants (Gossett et al. 1994; Gueta-Dahan et al. 1997; Mittova et al. 2004). Symbiotic $P$. indica fungus may promote the activation by plants antioxidant enzymes to scavenge the ROS (reactive oxygen species) (Rodriguez and Redman 2005; Baltruschat et al. 2008; Kumar et al. 2009). Increased antioxidant enzyme activity, including CAT (catalase), APX (ascorbate peroxidase), DHAR (dehydroascorbate reductase), MDHAR (monodehydroascorbate reductase), and GR (glutathione reductase), plays a significant role in tolerance to abiotic stressors. Baltruschat et al. (2008) point out that these enzyme activities are maintained at a high level in $P$. indica infected plants but decrease gradually in uninfected plants. $P$. indica stimulates antioxidant enzyme activities and prevents ROS formation by retarding the degradation of polyunsaturated lipids (Sun $e t$ al. 2010). However, compared to APX, CAT, and DHAR antioxidant enzymes, GR activity was the least affected by $P$. indica (Baltruschat et al. 2008; Kumar et al. 2009). Several reports have demonstrated that antioxidant enzyme activities are crucial for $P$. indica induced resistance against abiotic stress (Baltruschat et al. 2008, Vadassery et al. 2009; Sun et al. 2010).

Previous results were supported our results. Where, under salinity conditions antioxidant enzyme activity (CAT and POX) increased compared to control plants. Moreover, colonized plants by $P$. indica under salinity conditions shown increasing in antioxidant enzyme activity compared to non-colonized plants under salt stress, in all experimental plants species.

\section{Element content:}

It has been generally accepted that Am fungi would enhance nutrient uptake by infected plants under salinity conditions (Roa and Tak, 2002; Yano-Melo et al., 2003; Zandavalli et al., 2004).

Plants can use three strategies for the maintenance of low cellular/tissue $\mathrm{Na}^{+}$ concentration: sodium exclusion, sodium compartmentalization, and sodium secretion (Zhang et al. 2001). Sodium transport out of the cell can take place by the operation of plasma membrane-bound $\mathrm{Na}^{+} / \mathrm{H}^{+}$antiports. Transport mechanisms can also actively move ions across the tonoplast into the vacuole, removing the potentially harmful ions from the cytosol. These ions, in turn, act as an osmoticum within the vacuole (Shi et al. 2000; Mansoor et al. 2003). In this search, sodium content was increased in group two plants (treated by $100 \mathrm{mM} \mathrm{NaCl}$ ) compared to group one plants (control), in all experimental plant species. But, sodium content decrease in colonized plants by $P$. indica compared to non-colonized plants, under salinity conditions in all experimental plant species.

Rabie et al., (2005) reported that AM (arbuscular mycorrhiza) faba plants contained significant higher levels of $\mathrm{K}^{+}$, $\mathrm{Mg}^{2+}$ and $\mathrm{Ca}^{2+}$ ions, particularly in the presence of NFB, than non-Am plants at all salinity levels. Based on their results and on existing literatures, the greater salt tolerance of Am plants may be the result of the plant nutrition improvement under salinity stress. It is also noteworthy that $\mathrm{Na}^{+}$concentration in shoot system of AM faba plants, especially in the presence of NFB, at high salinity level was comparable to that of nonAm plants at moderate salinity level. These results are consistent with the previous work (Zandavalli et al., 2004; Rabie et al., 2005), and suggest that Am fungi may protect shoot system, mainly leaves, from $\mathrm{Na}^{+}$toxicity either by regulating $\mathrm{Na}^{+}$uptake from the soil or by accumulating it in root thereby delaying its translocation onto shoot system of infected plants. This may reflect the potential role of Am fungi for increasing plant $\mathrm{K}^{+}$and $\mathrm{Ca}^{2+}$ uptake more than $\mathrm{Na}^{+}$ under salinity stress. The role of $\mathrm{K}^{+}$and $\mathrm{Ca}^{2+}$ in salt adaptation of plants has been previously discussed by several authors. Parida and Das (2005) reported that when under salt stress; plants maintain high concentrations of $\mathrm{K}^{+}$and low concentrations of $\mathrm{Na}^{+}$in the cytosol. They do this by regulating the expression and activity of $\mathrm{K}^{+}$ and $\mathrm{Na}^{+}$transporters and of $\mathrm{H}^{+}$pumps that generate the driving force for transport. In addition, externally supplied $\mathrm{Ca}^{2+}$ reduces the toxic effects of $\mathrm{NaCl}$, presumably by facilitating higher $\mathrm{K}^{+} / \mathrm{Na}^{+}$selectivity. 
High salinity also results in increased cytosolic $\mathrm{Ca}^{2+}$ that is transported from the apoplast and intracellular compartments. The resultant transient $\mathrm{Ca}^{2+}$ increase potentialities stress signal transduction and leads to salt adaptation. Based on these data and existing literatures it is conceivable to conclude that Am symbioses may regulate the expression and activate $\mathrm{K}^{+}$and $\mathrm{Na}^{+}$transporters and $\mathrm{H}^{+}$ pumps that generate the driving force for transport. Besides, it may increase the transient $\mathrm{Ca} \mathrm{Ca}^{2+}$ from apoplast and intracellular compartments. This inference needs further investigation to support it. Rabie et al., (2005) reported that AM faba plants grew in high saline environments without any detectable signs of toxic effects of $\mathrm{NaCl}$, reflecting adaptation to high salinity. These extrapolations emphasized the prime role of Am fungi in increasing salinity tolerance of $f a b a$ plants up to $6.0 \mathrm{dSm}^{-1}$. These data suggest that selective accumulation or exclusion of ions, control of ion uptake by roots and transport into leaves and compartmentalization of ions at the cellular and whole plant levels are the most effective strategies of AM fungi for adaptation of $f a b a$ plants to salinity stress.

In the present search, calcium under salinity stress exhibited decrease in their content in $V$. faba and A. hypogea. But we obtained on opposite results in other plant species, where calcium content was increase in group two( treated with $100 \mathrm{mM} \mathrm{NaCl}$ ) compared to group one plants (control), in case $L$. termis and $H$. sabdariffa. In general, calcium content in group three $(P$. indica $+100 \mathrm{mM}$ $\mathrm{NaCl}$ ) was increase than in those in group two plants (treated with $100 \mathrm{mM} \mathrm{NaCl}$ ). Potassium under salinity stress didn't exhibit strong change in its content in group two compared to group one plants. Group three showed increasing in potassium content compared to group two plants.

\section{Reference:}

Abd-El Baki, B.G.K., Siefritz, F., Man, H.M., Weiner, H., Kaldenhoff, R., Kaiser, W.M. (2000). Nitrate reductase in Zea mays L. under salinity. Plant Cell Environ 23:515521

Akram, N.A., Ashraf, M. (2011). Improvement in growth, chlorophyll pigments and photosynthetic performance in salt-stressed plants of sunflower (Helianthus annuus L.) by foliar applicationof 5-aminolevulinic acid. Agrochimica 55:94-104

Apel, K., Hirt, H. (2004). Reactive oxygen species: metabolism, oxidative stress, and signal transduction. Annual Review of Plant Biology, 55: 373-399.

Arfan, M., Athar, H.R., Ashraf, M. (2007). Does exogenous application of salicylic acid through the rooting medium modulate growth and hoto synthetic capacity in two differently adapted spring wheat cultivars under salt stress? J Plant Physiology, 164:685-94.

Ashraf, M., Bashir, A. (2003). Salt stress induced changes in some organic metabolites and ionic relations in nodules and other plant parts of two crop legumes differing in salt tolerance. Flora, 198:486-498.

Ashraf, M., Harris, P.J.C. (2013). Photosynthesis under stressful environments: An overview. Photosynthetica, 51:163-90.

Ashraf, M., Foolad, M.R. (2006). Roles of glycine betaine and proline in improving plant abiotic stress resistance. Environ Exp Bot, 59:206-216.

Ashraf, M., Sultana, R. (2000). Combination effect of $\mathrm{NaCl}$ salinity and $\mathrm{N}$-form on mineral composition of sunflower plants. Biology Plant, 43:615-9.

Bagheri, A.A., Saadatmand, S., Niknam, V., Nejadsatari, T., Babaeizad, V. (2013). Effect of endophytic fungus, Piriformospora indica, on growth and activity of antioxidant enzymes of rice (Oryza sativa L.) under salinity stress. International journal of Advanced Biological and Biomedical Research, 1, (11): 13371350.

Ball, M.C., Farquhar, G.D. (1984). Photosynthetic and stomatal responses of two mangrove species, Avicennia marina and Aegiceras corniculatum, to long term salinity and humidity conditions. Plant Physiology, 1:1-6.

Baltruschat, H., Fodor, J., Harrach, B.D., Niemczyk, E., Barna, B., Gullner, 
G., Janeczko, A., Kogel, K.H., Scha"fer, P., Schwarczinger, I., Zuccaro, A., Skoczowski, A. (2008) Salt tolerance of barley induced by the root endophytePiriformosporaindica is associated with a strong increase in antioxidants. New Phytologist, 180: 501-510.

Bates, L.S., Waldren, R.P., Teare, I.D. (1973): Rapid determination of free proline for water-stress studies. Plant Soil, 39:205-207.

Beers, R.F., Sizer, I.W. (1952). A spectrophotometric method for measuring the breakdown of hydrogen peroxide by catalase. J Biol Chem, 195: 133-140.

Behboudian, M.H., Torokfalvy, E., Walker, R.R. (1986). Effects of salinity on ionic content, water relations and gas exchange parameters in some citrus scion rootstock combinations. Sci Hortic, 28:105-116.

Belkhodja, R., Morales, F., Abadia, A., Gomez-Aparisi, J., Abadia, J. (1994). Chlorophyll fluorescence asa possible tool for salinity tolerance screening in barley (Hordeum vulgare L.). Plant Physiol, 104:667673.

Chordia, P. (2011). Salt stress on axenic growth of Piriformospora indica. M.Phil Thesis, Amity University, Uttar Pradesh.

Criddle, R.S., Hansen, L.D., Breidenbach, R.W., Ward, M.R., Huffaker, R.C. (1989). Effects of $\mathrm{NaCl}$ on metabolic heat evolution rates by barley roots. Plant Physiology, 90: 53-58.

Dionisio-Sese, M.L., Tobita, S. (1998). Antioxidant responses of rice seedling to salinity stress. Plant Sci, 135:1-9.

Downton, W.J.S. (1977). Photosynthesis in salt stressed grapevines. Aust Plant Physiol, 4:183-192.

Flexas, J., Bota, J., Escalona, J.M., Sampol, B., Medrano, H. (2002). Effects of drought on photosynthesis in grapevines under field conditions: an evaluation of stomatal and mesophyll limitations. Functional Plant Biology, 29: 461-471.
Foyer, C.H., Noctor, G. (2000). Oxygen processing in photosynthesis: regulation and signalling. New Phytol, 146:359-388.

Foyer, C,H,, Noctor, G. (2000). Oxygen processing in photosynthesis: regulation and signalling. New Phytologist, 146: 359-388.

Goas, G., Goas, M., Larher, F. (1982). Accumulation of free proline and glycine betaine in Astertripolium subjected to a saline shock: a kinetic study related to light period. Physiol Plant, 55:383-388.

Gomathi, R., Rakkiyapan, P. (2011). Comparative lipid peroxidation, leaf membrane thermostability, and antioxidant system in four sugarcane genotypes differing in salt tolerance. International Journal of Plant Physiology and Biochemistry, 3(4): 67-74.

Gonzalez, L., Gonzalez-vilar, M. (2001). Determination of relative water content. In: REIGOSA, M.J. Handbook of plant ecophysiology techniques. Dordrecht: Kluwer Academic, 2001. p.207-212.

Gossett, D.R., Millholion, EP, Lucas MC, Bands, S.W., Marney, M.M. (1994). The effects of $\mathrm{NaCl}$ on antioxidant enzyme activities in callus tissue of salt tolerant and salt sensitive cotton cultivars. Plant Cell Rep, 13:498503.

Gossett, D.R., Millhollon, E.P., Lucas, M.C. (1994). Antioxidant responseto $\mathrm{NaCl}$ stress in salt-tolerant and saltsensitive cultivars of cotton. Crop Science, 34: 706-714.

Gueta-Dahan, Y., Yaniv, Z., Zilinskas, B.A., Ben-Hayyim, G. (1997). Salt and oxidative stress: similar and specific responses and their relation to salt tolerance in Citrus. Planta, 203:460 469.

Gueta-Dahan, Y., Yaniv, Z., Zilinskas, B.A., Ben-Hayyim, G. (1997). Salt and oxidative stress: similar and specific responses and their relation to salt tolerance in Citrus. Planta, 203: 460469.

Hajlaoui, H., Ayeb, N.E., Garrec, J.P., Denden, M. (2010). Differential effects of salt stress on osmotic 
adjustment and solutes allocation on the basis of root and leaf tissue senescence of two silage maize (Zea mays L.) varieties. Ind Crops Prod, 31:122-130.

Herna'ndez, J.A., Jime'nez, A., Mullineaux, P.M., Sevilla, F. (2000). Tolerance of pea (Pisum sativum L.) to longterm salt stress is associated with induction of antioxidant defences. Plant Cell Environ, 23:853-862.

Hernández, J.A., Jiménez, A., Mullineaux, P.M., Sevilla, F. (2000). Tolerance of pea (Pisum sativumL.) to longterm salt stress is associated with inductionof antioxidant defenses. Plant, Cell \& Environment, 23: 853862.

Hernandez, J.A., Olmos, E., Corpas, F.J., Sevilla, F., del Rio, L.A. (1995). Salt induced oxidative stress in chloroplasts of pea plants. Plant Sci, 105:151-167.

Humphrjes, A.A., J.R., (1956). A study of meiosis in coelomic and oviducal oocytes of Triturus viridescens, with particular emphasis on the origin of spontaneous polyploidy and the effects of heat shock on the first meiotic division. J. Morphol., 99: 97-136.

Jamil, M., Lee, K.B., Jung, K.Y., Lee, D.B., Han, M.S., Rha, E.S. (2007). Salt stress inhibits germination and early seedlinggrowth in cabbage (Brassica oleracea capitataL.). Pak J Biol Sci, 10:910-4.

Jiang, M., Zhang, J. (2002). Water stressinduced abscisic acid accumulation triggers the increased generation of reactive oxygen species and upregulates the activities of antioxidant enzymes in maize leaves. J Exp Bot, 53:2401-2410.

Jogawat, A., Saha, S., Bakshi, M., Dayaman, V., Kumar, M., Dua, M., Varma, A., Oelmüller, R., Tuteja, N., Johri, A.K. (2013). Piriformospora indica rescues growth diminution of rice seedlings during high salt stress. Plant Signaling \& Behavior, 8:e26891; PMID: 24169531.

Jolivet, Y., Pireaux, J.C., Dizengremel, P. (1990). Changes in properties of barley leaf mitochondria isolated from NaCl-treated plants. Plant Physiology, 94: 641-646.

Kafer, E. (1977). Meiotic and mitotic recombination in Aspergillus and its chromosomal aberrations. Advances in Genetics, 19: 33-131.

Kaya, C., Ashraf, M., Sonmez, O., Aydemir, S., Levent, Tuna, A., Cullu, A.M. (2009). The influence of arbuscular mycorrhizal colonisation on key growth parameters and fruit yield of pepper plants grown at high salinity. Sci Hortic, 121:1-6.

Kaya, C., Kirnak, H., Higgs, D. (2001b). Enhancement of growth and normal growth parameters byfoliar application of potassium and phosphorus in tomato cultivars grown at high $(\mathrm{NaCl})$ salinity. J Plant Nutr, 24:357-367.

Kumar, M., Sharma, R., Jogawat, A., Singh, P., Dua, M., Gill, S.S., Trivedi, D.K., Tuteja, N., Varma, A.K., Oelmueller, R., Johri, A.K. (2012). Piriformospora indica, a root endophytic fungus, enhances abiotic stress tolerance of the host plant. In: Tuteja N, Gill SS, Tiburcio AF, Tuteja R (eds) Improving crop resistance to abiotic stress. WileyBlackwell, Weinheim, pp 543-548.

Kumar, M., Yadav, V., Tuteja, N., Johri, A.K. (2009). Antioxidant enzyme activities in maize plants colonized with Piriformospora indica. Microbiology, 155:780-790.

Laemmli, V.K. (1970). Cleavage of structural proteins during assembly of the head of bacteriophage T4. Nature, 277: 680-685.

Lowery, O.H., Rosebrough, N.J., Farr, A.L., Randall, R.J. (1951). Protein measurement with the folin phenol reagent. J. Biol. Chem, 193: 265275.

Machly, A.C., Chance, B. (1954). The assay of catalase and peroxidase, In: Methods of Biochemical Analysis. Vol. I Ed. David Glick, Inter-Sci. Publications Inc., New York,354428.

Mansour, M.M.F., Salama, K.H.A., AlMutawa, M.M. (2003): Transport proteins and salt tolerance in plants. Plant Sci, 164: 891-900. 
Maslenkova, L.T., Miteva, T.S., Popoval, P. (1999). Changes in the polypeptide patterns of barley seedling exposed to jasmonic acid and salinity. Plant Physiology, 98: 700-707.

Metzner, H., Rau, H., Senger, H. (1965). Untersuchungen

zur synchronisierbarkeit einzelner pigmentmangel Mutanten von Chlorella. Planta 65:186-194.

Mittler, R. (2002). Oxidative stress, antioxidants and stress tolerance. Trends Plant Sci 7:405-410.

Mittova, V., Guy, M., Tal, M., Volokita, M. (2004). Salinity up-regulates the antioxidative system in root mitochondria and peroxisomes of the wild salt-tolerant tomato species Lycopersicon pennellii. Journal of Experimental Botany, 55:11051113.

Munns, R., Tester, M. (2008). Mechanisms of salinity tolerance. Annual Reviewof Plant Biology 59: 651681.

Neto, A.D.A., Prisco, J.T., Gomes-Filho, E. (2009). Changes in soluble amino-N, soluble proteins and free amino acids in leaves and roots of salt-stressed maize genotypes. J Plant Interact, 4:137-144.

Parida, S.K., Das, A.B. (2005 ). Salt tolerance and salinity effects on plants, Ecotoxicol. Environ. Safety, 60 (3): 324-349.

Pascal, S.D., Maggio, A. and Barbieri, G. (2005). Soil salinization affects growth, yield and mineral composition of cauliflower and broccoli. Eur. J. Agron., 23: 254264.

Perveen, S., Shahbaz, M., Ashraf, M. (2010). Regulation in gas exchange and quantum yield of photosystem II(PSII) in salt stressed and nonstressed wheat plantsraised from seed treated with triacontanol. Pak J Bot, 42:3073-81

Rabie, G.H., Aboul-Nasr, M.B., AlHumiany, A. (2005). Increase salinity tolerance of cowpea plants by dual inoculation of AM fungus Glomus clarum and Nitrogen- fixer Azospirillum brasilense .Mycobiology, 33(1): 51-61.
Rao, A.V., Tak, R. (2002). Growth of different tree species and their nutrient uptake in limestone mine spoil as influenced by arbuscular mycorrhizal (AM) fungi in India arid zone. J. Arid Environ, 51: 113-119.

Rodriguez, R.J., Redman, R.S. (2005). Balancing the generation and elimination of reactive oxygenspecies. Proc Natl Acad Sci USA 102:3175-3176

Rodriguez, R.J., Redman, R.S., Henson, J. (2004). The role of fungal symbiosesin the adaptation of plants to high stress environments. Mitigation andAdaptation Strategies for Global Change, 9: 261-272.

Shannon, M.C. (1997). Adaptation of plants to salinity. Advances in Agronomy, 60: 75-120.

Shi, H, Ishitani, M., Kim, C., Zhu, J.K. (2000). The Arabidopsis thaliana salt tolerance gene SOSI encodes a putative $\mathrm{Na}^{+} / \mathrm{H}^{+}$antiporter. Proc. Natl. Acad. Sci. USA, 97: 68966901.

Spychalla, J.P., Desbough, S.L. (1990). Superoxide dismutase, catalase, and alpha-tocopherol contentof stored potato tubers. Plant Physiol, 94:1214-1218.

Stewart, C.R., Lee, J.A. (1974). The rate of proline accumulation in halophytes. Planta, 120:279-289.

Sun, C., Johnson, J.M., Cai, D., Sherameti, I., Oelmuller, R., Lou, B. (2010). Piriformospora indica confers drought tolerance in Chinese cabbage leaves by stimulating antioxidant enzymes, the expressionof drought-related genes and the plastid-localized CAS protein. J Plant Physio, 1167:10091017

Taiz, L., Zeiger, E. (2002). Plant physiology, 3rd Edit.,Sinauer Ass., Sunderland.

Vadassery, J., Tripathi, S., Prasad, R., Varma, A., Oelmu"ller, R. (2009). Monodehydroascorbatereductase 2 and dehydroascorbatereductase 5 are rucial for a mutualistic interaction between Piriformospora indica and Arabidopsis. J Plant Physiol, 166:1263-1274. 
Varma, A., Verma, S., SudhaSahay, N., Bütehorn, B., Franken, P. (1999). Piriformospora indica, a cultivable plant-growth-promoting root endophyte. Applied Environmental Microbiology, 65: 2741-2744.

Verma, S., Varma, A., Rexer, K.H., Hassel, A., Kost, G., Sarabhoy, A., Bisen, P,Bütenhorn, B., Franken, P. (1998). Piriformospora indica, gen. et sp.nov., a new root-colonizing fungus. Mycologia, 90: 896-903.

Waller, F., Achatz, B., Baltruschat, H., Fodor, J., Becker, K., Fischer, M., Heier, T., Hückelhoven, R., Neumann, C., Wettstein, D. et al. (2005). The endophytic fungus Piriformospora indica reprograms barley to salt-stress tolerance, disease resistance, and higher yield. Proceedings of the National Academy of Sciences USA, 102: 13386-13391.

Wojtaszek, P. (1997). Oxidative burst: an early plant response to pathogen infection. Biochem J, 322: 681-692.

Wolf, B. (1982). A comprehensive system of leaf analysis and its use for diagnosing crop nutrient status. Commun. Soil Sci. Plant Anal, 13: 1035-1059.

Yano-Melo, A.M., Saggin, O.J., Maia, L.C. (2003). Tolerance of mycorrhized banana (Musa sp. cv. Pacovan) plantlets to saline stress.
Agric.Ecosystems and Environ, 95 (1): 343-348.

Yeo AR, Yeo, M.E., Flowers, S.A., Flowers, T.J. (1990). Screening of rice (Oryza sativa L.) genotypes for physiological characters contributing to salinity resistance, and their relationship to overall performance. Theoretical Applied Genetics, 79:377-384.

Zandavalli, R.B., Dillenburg, L.R. and Paulo, V.D. (2004). Growth responses of Araucaria angustifolia (Araucariaceae) to inoculation with the mycorrhizal fungus Glomus clarum. Agric. Ecosyst. Environ. Applied Soil Ecol., 25: 245-255.

Zarea, M.J., Hajinia, S., Karimi, N., MohammadiGoltapeh E, Rejali F, Varma, A. (2011b). Effect of Piriformospora indica and Azospirillum strains from saline or non-saline soil on mitigation of the effects of $\mathrm{NaCl}$. Soil Biol Biochem 45:139-146

Zhang, H.X., Hodsom, J.N., Williams, J.P. and Blumwald, E. (2001). Engineering salt-tolerant Brassica plants: Characterization of yield and seed oil quality in transgenic plants with increased vacuolar sodium accumulation. Proc. Natl. Acad. Sci. USA 98: 12832-12836.

قد تبين أن المعاملة بفطر البرفورموسبورا انديكا لبعض نباتات المحاصيل مثل الفول البلدى، و الترمس، و الفول السودانى،

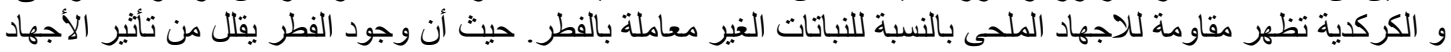

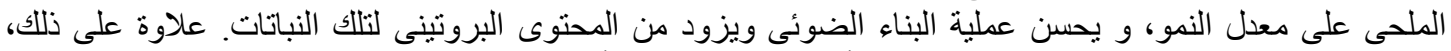

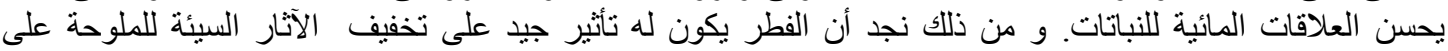

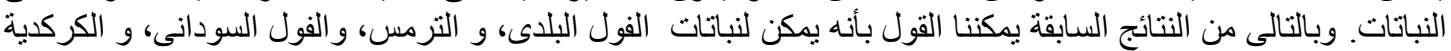

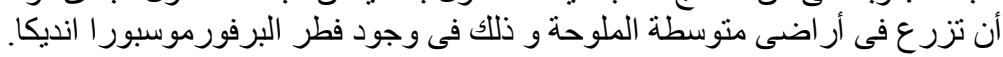

